\title{
IMPLEMENTASI HUKUM TATA NEGARA PADA PEMILIHAN KEPALA DAERAH DALAM PANDEMI VIRUS CORONA 2019 ( COVID -19)
}

\author{
Yustiana Dwirainaningsih ${ }^{1)}$, Salman Al Farasi ${ }^{2}$ ) \\ ${ }^{1,2}$ Politeknik Pusmanu, Universitas Pekalongan \\ Email: ${ }^{1}$ rainapk1@ politeknikpusmanu.ac.id, ${ }^{2}$ salman@unikal.ac.id
}

\begin{abstract}
The speread of Corona Virus Disease 2019 (COVID-19) as a non-natural national disaster requires handling policies and extraordinary steps both at the central and regional levels including the need to postpone the implementation stages of the election for governors and deputy governors, regents and deputy regents, as well as mayors and deputies Concurrent mayor in 2020. The implementation of regional head elections has the aim that the election for governors and deputy mayors can continue in a democratic and quality manner and to maintain domestic political stability, on the orther hand health is maintained by strict health protocol at everystage of selection. The impact of the non-natural disaster pandemic Corona Virus Disease (Covid-19) wich occurred several moths ago resulted in the simultaneous Regional Head Election which was originally scheduled for September 2020 to be postponed to December 2020 in accordance with the issuance of a Government Regulation in Lieu Of Law Number 2 of 2020 wich is technically made by the General Election Commissions. General Election Commissions Regulation Number 6 of 2020.The research method uses the normative legal writing method and aims to provide on explanarion regarding the contitusional law perspective on the implementation of simultaneous regional head election in the mudst of a non-natural disaster pandemic Corona virus Deisease ( Covid-19). The research results are expected to contribute to scientific development in the field of law.
\end{abstract}

Keywords: Implementation of Constitutional Law, Regional Head Elections, Corona Pandemic Virus Disease (Covid-19)

\section{PENDAHULUAN}

Secara geografis Indonesia adalah negara yang sangat besar dengan jumlah penduduknya, juga memiliki kekayaan alam dan budaya yang beraneka ragam, oleh karena itu Indonesia merupakan sebuah negara besar yang perlu diatur dari sisi hukum sesuai dengan dasar negara Indonesia. Di dalam Undang-Undang Dasar Negara Republik Indonesia Tahun 1945 disebutkan bahwa Indonesia adalah Negara Hukum.

Menurut Pasal 18 Ayat (4) UUD RI Tahun 1945 bahwa kepala daerah dipilih secara demokratis. Pemilihan umum kepala daerah adalah pemilihan umum yang dilaksanakan di tingkat daerah guna memilih pemimpin daerah. Menurut Undang-Undang Nomor 23 Tahun 2014 bahwa kepala dan wakil kepala daerah dipilih oleh rakyat di daerah itu sendiri secara langsung melalui pilkada. Penyelenggaraan pemilihan kepala daerah yang bebas dan berkala prasyarat merupakan salah satu sistem politik demokrasi, pemerintah demokrasi wajib untuk melaksanakan pilkada dalam waktu yang sudah ditentukan

Sebuah negara akan bertumpu pada 3 (tiga) hal yaitu legislatif, eksekutif dan yudikatif. Indonesia merupakan negara yang menerapkan teori trias politika tidak murni, baik sebelum maupun sesudah amandemen. Hal ini merupakan langkah yang baik dalam menjalankan sistem pemerintahan yang efektif sesuai dengan fungsinya pada negara demokrasi. Di masa pandemi Covid-19 Indonesia menjadi salah satu yang menyelenggarakan pemilihan kepala daerah 
secara langsung. Dalam pemilihan kepala daerah dan wakil kepala daerah secara langsung oleh masyarakat memiliki hak legitimasi memilih yang sangat kuat dan lebih besar dibandingkan dalam pemilihan oleh DPRD. Pemilihan kepala daerah langsung merupakan satu hal yang terkait dengan cita-cita reformasi yang dapat memberikan rasa percaya dan dapat mengembalikan kedaulatan di tangan.

Pemilihan kepala daerah dan wakil kepala daerah yang saat ini diselenggarakan untuk memperkuat otonomi daerah dalam kerangka Negara Kesatuan Republik Indonesia. Pelaksanaannya tetap berpedoman terhadap Undang-Undang No. 23 Tahun 2014 dengan mengetahui pada prinsip-prinsip pemberian otonomi daerah yang terdapat pada UndangUndang tersebut.

Penyelenggaraaan pemilihan umum ada pada $209 \mathrm{kota} / \mathrm{kabupaten/provinsi} \mathrm{di} \mathrm{mana} \mathrm{Kota}$ Pekalongan menjadi salah satu untuk bisa menyelenggarakan pilkada serentak di saat pandemi ini. Ketua KPU mengatakan, dalam pilkada tersebut tentu KPU dituntut maksimal dalam menyosialisasikan tentang bagaimana pentingnya partisipasi masyarakat guna menyukseskan pilkada, tentunya dalam masa pandemi di mana semua aktivitas wajib mengikuti regulasi protokol kesehatan. Pilkada langsung dan dilaksanakan serentak mendorong penyelenggara untuk bisa terciptanya keadaannya secara efisiensi dan efektivitas dalam menghemat anggaran di samping itu juga menghemat tenaga dan waktu.

Hal terpenting dalam pilkada adalah mengenai tanggal pelaksanaan karena pelaksanaan pilkada serentak masih sangat sulit akibat Covid-19, dikarenakan di Indonesia jumlah pederita serta angka kematiannya masih cukup tinggi termasuk di Kota Pekalongan dan belum bisa terkendali. Penyelenggara dalam hal ini KPU (Komisi Pemilihan Umum) secara langsung bertanggung jawab sepeneuhnya dalam memberikan petunjuk dan arahan terkait dengan protol kesehatan dan mitigasi risiko untuk mengurangi risiko yang ada, di samping itu juga menerangkan tahapan dalam pilkada sesuai dengan protokol kesehatan agar masyarakat yang datang untuk memilih jangan sampai khawatir untuk datang ke TPS dalam menyalurkan hak pilihnya karena takut tertular Covid-19.

Pilkada serentak perlu kerja sama dalam mengisyaratkan dari segi proses pelaksanaannya, terutama penyelenggara pemilu, pengawas pemilu dan partai politik sehingga tercipta demokrasi sehingga dapat berjalan sesuai dengan berkeadaban (democratic civility). Dalam cita-cita demokrasi menciptakan kesetaraan serta keadilan untuk meminimalisir terjadinya suatu benturan (clash), dalam berbagai masalah kepentingan. Tujuan dalam kajian hukum tata negara diperlukan suatu penjelasan yang terkait dengan perspektif dalam pemilihan umum serentak disaat wabah Covid-19.

\section{RUMUSAN MASALAH}

Penelitian ini memberikan satu penjelasan yang terkait dengan perspektif hukum tata negara terhadap suatu pelaksanaan pemilihan kepala daerah serentak di tengah wabah bencana nonalam pandemi Corona Virus Disease (Covid-19). Berdasarkan hal tersebut, penulis tertarik untuk mengkaji implementasi hukum tata negara terutama dalam pemiliham kepala daerah serentak di saat pandemi Corona Virus Disease (Covid 19).

\section{TINJUAN PUSTAKA}

Perundang-undangan dan hukum merupakan peraturan yang tidak boleh ditetapkan oleh satu pihak saja ataupun salah satu golongan saja, karena hukum dibuat untuk menjamin keadilan serta kepentingan semua warga masyarakat umum, oleh sebab itu hukum bukan sebagai absolute rechsstaat melainkan democratische rechsstaat. Hukum adalah sebuah satu kesatuan yang terwujud dalam tata norma yang berpuncak dalam satu konstitusi. Suatu negara yang memerintah adalah hukum bukan manusia.

\subsection{Pemilu (Pemilihan Umum)}

Dalam negara demokrasi bahwa pemilihan umum merupakan unsur yang sangat penting, merupakan parameter mengukur demokratis tidaknya suatu negara adalah dari bagaimana perjalanan pemilu yang dilaksanakan oleh negara tersebut. Demokrasi adalah suatu bentuk 
pemerintahan oleh rakyat (G. Sorensen, 2013). Pada dasarnya pemilu adalah sarana pelaksanaan kedaulatan rakyat yang diselenggarakan secara langsung, umum, bebas, rahasia, jujur, dan adil dalam Negara Kesatuan Republik Indonesia berdasarkan Pancasila dan Undang-Undang Dasar Negara Republik Indonesia Tahun 1945

Salah satu fungsi dari sebuah lembaga pemilu adalah menyelenggarakan pemilihan umum. Fungsi dari penyelenggaraan pemilu terdiri dari KPU dan Badan Pengawas Pemilu yang merupakan satu kesatuan yang tidak bisa dipisahkan..

\subsection{Demokrasi}

Demokrasi bila ditinjau dari terminologis, sebagaimana dikemukakan beberapa para ahli, misalnya:

a. Joseph A. Schmeter, bahwa demokrasi adalah bagaimana mekanisme kelembagaan nagara mencapai sesuatu untuk membuat keputusan melalui perjuangan kompetensi dalam memperoleh suara rakyat.

b. Sidney Hook, bahwa demokrasi merupakan bentuk pemerintahan di mana keputusan-keputusan pemerintah yang penting secara langsung atau tidak langsung didasarkan pada kesepakatan mayoritas yang diberikan secara bebas dari rakyat dewasa.

c. Phillipe C. Schmitter dan Terry Lynn Karl yang menyatakan bahwa demokrasi sebagai suatu sistem pemerintahan di mana pemerintah dimintai tanggung jawab atas tindakan-tindakan mereka di wilayah publik oleh warga negara yang bertindak secara tidak langsung melalui kompetisi dan kerja sama dengan para wakil mereka yang telah terpilih.

d. Henry B. Mayo, bahwa demokrasi merupakan suatu sistem politik yang menunjukkan bahwa kebijakan umum ditentukan atas dasar mayoritas oleh wakilwakil yang diawasi secara efektif oleh rakyat dalam pemilihan-pemilihan berkala yang didasarkan atas prinsip kesamaan politik dan diselenggarakan dalam suasana terjaminnyakebebasan politik e. Affan Gaffar, bahwa demokrasi terbagi dalam dua bentuk yaitu pemaknaan secara normatif, ialah demokrasi yang secara ideal hendak dilakukan oleh suatu negara, dan pemaknaan secara empirik, yaitu demokrasi dalam perwujudannya pada dunia politik praktis (Suara.com, 2021).

Berdasarkan berbagai pendapat di atas, maka dapat ditarik suatu pengertian dasar bahwa demokrasi suatu sistem pemerintahan di mana kekuasaan berada di tangan rakyat, yang mengandung tiga unsur, yaitu pemerintahan dari rakyat, oleh rakyat, dan untuk rakyat. Pemerintahan dari rakyat mengandung pengertian bahwa pemerintah yang akan berdaulat adalah pemerintah yang mendapatkan dukungan dan pengakuan oleh rakyat. Legitimasi suatu pemerintahan sangat penting karena dengan legitimasi tersebut, pemerintahan berdaulat adalah apabila dapat menjalankan pemerintahannya serta programprogram sebagai wujud dari amanat dari rakyat yang diberikan kepadanya.

\section{METODE PENELITIAN}

Metode yang digunakan dalam penelitian ini menggunakan metode hukum normatif, dengan menggunakan pendekatan perundangundangan doktrinal dan pendekatan konseptual. Pengumpulan bahan studi hukum melalui studi kepustakaan (library research). Melalui cara mengumpulkan bahan hukum primer, bahan hukum sekunder serta bahan hukum tersier. Bahan hukum primer merupakan bahan hukum yang bersifat autoritatif artinya mempunyai otoritas, bahan hukum ini berbentuk undangundang, dan putusan hakim, sedangkan bahan hukum sekunder berupa publikasi tentang hukum di luar perundang-undangan (Marzuki, 2017). Sedangkan bahan hukum tersier berupa kamus atau ensiklopedia untuk mengkaji gramatikal dari permasalahan ini (Susanti dan Others, 2015). Bahan hukum dalam teknik analisisnya menggunakan deskritif analitik yaitu menghubungkan antara premis mayor dan premis minor serta memberikan penjelasan secara mendetail terkait isu yang diangkat sehingga dapat ditarik kesimpulan. 


\section{HASIL PENELITIAN DAN PEMBAHASAN}

\subsection{Hasil Penelitian}

Sebelum pelaksanaan pemilihan kepala daerah secara serentak yang akan dilaksanakan pada tanggal 23 September 2020, namun pemerintah dan Dewan Perwakilan Rakyat secara bersamaan memutuskan untuk menunda dalam pelaksanaan pilkada disebabkan oleh wabah Covid-19. Komisi Pemilihan Umum sebagai salah satu penyelenggara pemilu telah mengambil langkah-langkah yaitu dengan jalan melakukan penundaan dalam tahapan pilkada dengan mengeluarkan Surat Keputuan Nomor 179/PL.02-Kpt/01/KPU/III/2020, dan Presiden menetapkan Perpu Nomor 2 tahun 2020 kemudian ditetapkan menjadi Undang-Undang yaitu Undang-Undang Nomor 6 Tahun 2020. Dalam undang-undang tersebut sudah dipastikan bahwa pemerintahan akan memberikan kepastian hukum apabila akan melaksanakan pemilihan kepala daerah secara serentak di tengah pandemic Covid-19 hal ini tertuang dalam Pasal 201A ayat 2 ditegaskan pelaksanaan pilkada serentak jatuh pada tanggal 9 Desember 2020. Berdasarkan Undang-undang tersebut maka KPUD Kota Pekalongan akan melaksanakan pemilihan Walikota dan Wakil Walikota Pekalongan. Dalam pilkada serentak ini KPUD menetapkan 2 ( dua ) bakal calon. Ada beberapa tahapan dalam penyelenggaraan pilkada di Kota Pekalongan yaitu:

1) Penyusunan Daftar Pemilih

Komisioner KPU Kota Pekalongan Divisi Perencanaan Data dan Informasi Mursyid Salimi mengatakan, pasca pelaksanakan Pilwalkot Pekalongan Tahun 2020, KPU Kota Pekalongan melakukan Rekapitulasi Pemutakhiran Data Pemilih Berkelanjutan secara periodik. Hal itu sesuai dengan Surat Edaran Ketua KPU RI Nomor 366/PL.02-SD/01/KPU/IV/2021 tentang Perubahan Surat Ketua KPU RI Nomor 132/PJ.02SD/01/KPU/II/2021perihal Pemuakhiran Data Pemilih berkelanjutan Tahun 2021.

Mursyid Salimi menjelaskan bahwa agenda penting pada Rapat Pleno DPHP tersebut untuk mengetahui berapa jumlah calon Daftar Pemilih Tetap (DPT), dan dari DP4 (Daftar Penduduk Potensial Pemilih Pemilihan) yang kemudian menjadi DPS, Jumlah total se-Kota Pekalongan dari 27 kelurahan 539 TPS.

Tabel 1 Jumlah Pemilih Kota Pekalongan

\begin{tabular}{cc}
\hline Pemilih & Jumlah \\
\hline Laki-laki & 111.784 \\
Perempuan & 111.820 \\
Total & 223.604
\end{tabular}

2) Pencalonan dan Penetapan Bakal Calon

Berdasarkan Keputusan KPUD Kota

Pekalongan Nomor 90/PP.01.2-

Kpt/3375/KPU-Kot/VI/2020 tentang

Perubahan Ketiga atas Keputusan Komisi Pemilihan Umum Kota Pekalongan Nomor Nomor 150/PP.01.2-Kpt/3375/KPUKot/IX/2019 tentang Pedoman Teknis Tahapan, Program dan Jadwal Penyelenggaraan Pemilihan Walikota dan Wakil Walikota Pekalongan Tahun 2020, dengan ini KPU Kota Pekalongan mengumumkan Bakal Pasangan Calon Walikota dan Wakil Walikota Pekalongan Tahun 2020 yang telah mendaftar di KPU Kota Pekalongan. Dalam pelaksanaan pendaftaran pilkada tahun 2020 tidak boleh melakukan kegiatan iring-iringan atau arak-arakan saat pada waktu pendaftaran hal ini harus sesuai dengan PKPU Nomor 13 Tahun 2020 tertuang dalam Pasal 49 Ayat 1 mengenai tata cara pendaftaran harus sesuai dengan protokol kesehatan guna mencegah dan mengendalikan Covid19. Di Kota Pekalongan terdapat 2 (dua) pasangan bakal calon yang mendaftarkan sebagai Walikota dan Wakil Walikota. Adapun bakal Calon Walikota dan Wakil Walikota adalah :

\begin{tabular}{|c|c|c|c|}
\hline No & Nama Paslon & $\begin{array}{c}\text { Partai } \\
\text { Pengusung }\end{array}$ & $\begin{array}{c}\text { Status } \\
\text { Penilaian } \\
\text { Berkas }\end{array}$ \\
\hline 1 & $\begin{array}{l}\text { H. } \\
\text { Afzan Arslan } \\
\text { Djunaid, SE; } \\
\text { dengan } \\
\text { H. Salahudin, } \\
\text { STP }\end{array}$ & $\begin{array}{l}\text { - PDI-P } \\
\text { - PPP } \\
\text { - Hanura } \\
\text { - PAN }\end{array}$ & $\begin{array}{c}\text { Memenuhi } \\
\text { Syarat }\end{array}$ \\
\hline 2 & $\begin{array}{l}\text { Hj. Balgis Diab, } \\
\text { SE, S.Ag, MM; } \\
\text { dengan } \\
\text { Moch. } \\
\text { Machrus, Lc, } \\
\text { M.Si }\end{array}$ & $\begin{array}{l}\text { - Gorkar } \\
\text { - PKB } \\
\text { - PKS } \\
\text { - Garindra } \\
\text { - Nasdem }\end{array}$ & $\begin{array}{c}\text { Memenuhi } \\
\text { Syarat }\end{array}$ \\
\hline
\end{tabular}


3) Masa Kampaye

Dalam pemilu, kampanye merupakan salah satu program yang penting untuk mendukung pemilihan umum (pemilu) di mana dalam kegiatan tersebut para bakal pasangan calon memperkenalkan dan memaparkan visi dan misinya kepada masyarakat. Menurut Pasal 267 Ayat (1) dan (2) Undang-Undang Nomor 7 Tahun 2017 definisi dari kampanye adalah suatu pendidikan politik diberikan kepada masyarakat dan dilakukan dengan tanggung jawab moral dan secara serentak. Pada kondisi pandemi, melaksanakan kegiatan kampanye berbeda dan tidak mudah, ruang untuk pasangan calon untuk mengumpulkan massa dalam jumlah besar (kampanye rapat umum) hampir dipastikan tidak boleh dilaksanakan. Ada hal baru dalam mekanisme kampanye yang semestinya mekanisme kampanye dengan mengumpulkan massa dalam jumlah yang besar masih menjadi proses elektoral yang sangat identik dalam pelaksanaan pesta demokrasi lokal di Indonesia. Hal yang paling memungkinkan dilakukan adalah melakukan kampaye dengan metode daring (online) di setiap pelaksnaan kampanye dan hal ini juga dibatasi terkait dengan keterbatasan di bidang sarana dan prasarana.

4) Pemungutan Suara dan Perhitungan suara

Puncak dari kegiatan pilkada ini adalah setiap pemilih mempunyai hak politiknya dalam tahapan ini pemilih dapat dan bebas secara mandiri tidak ada tekanan dari pihak manapun untuk menyalurkan hak politiknya untuk dapat memilih calon kepala daerah berdasarkan hati nurani di pilihannya di bilik suara. Pada kegiataan pemungutan suara harus berdasarkan dan wajib untuk menerapkan protocol kesehatan dan dilaksanakan secara maksimal pada waktu pemungutan suara pemilihan Walikota dan Wakil Walikota Pekalongan tahun 2020 di setiap Tempat Pemungutan Suara (TPS).
Tabel 3 Hasil Perhitungan Suara

\begin{tabular}{clc}
\hline No & \multicolumn{1}{c}{ Nama Paslon } & Hasil \\
\hline 1 & H. Achmad Afzan Arslan & $55,2 \%$ \\
& $\begin{array}{l}\text { Djunaid, SE dengan H. } \\
\text { Salahudin, STP }\end{array}$ \\
2 & Hj. Balgis Diab, SE, S.Ag, & $44,8 \%$ \\
& MM dengan Moch. \\
& Machrus, Lc, M.Si
\end{tabular}

\subsection{Pembahasan}

\subsubsection{Pemilihan Kepala Daerah Serentak menurut Pasal 1 Angka 2 Undang- Undang Nomor 23 Tahun 2014 tentang Pemerintahan Daerah}

Pada intinya pemerintah daerah dalam menyelenggarakan urusan pemerintahan berada di tangan pemerintahan daerah dan Dewan Perwakilan Rakyat dalam menjalankan tugasnya harus sesuai dengan asas otonomi dengan prinsip seluas-luasnya dengan prinsip ekonomi seluas-luasnya dengan melihat sistem dan prinsip Negara Kesatuan Republik Indonesia. Daerah kabupaten/kota selain berstatus sebagai daerah merupakan wilayah administratif yang menjadi wilayah kerja bagi bupati/walikota terpilih dalam memyelenggarakan urusan pemerintahan umum (Kristian, 2017).

Pilkada secara langsung atau serentak yang sekarang diterapkan di Indonesia merupakan koreksi dari sistem pilkada terdahulu, sebagai perwujudan dalam pengembalian hak-hak dasar masyarakat yang ada di wilayah tersebut dengan memberikan suatu kewenangan penuh dalam rangka pemilihan kepala daerah dan berharap bisa mendorong suatu dinamika dalam kehidupan demokrasi di daerah atau ditingkat lokal.

Pilkada Kota Pekalongan tahun 2020 diadakan dalam rangka untuk memilih Walikota dan Wakil Walikota Kota Pekalongan periode 2021 - 2024 oleh sebab itu pilkada ini bersifat lokal yang diselenggarakan oleh KPU Kota Pekalongan. Oleh karena itu Keputusan KPU Kota Pekalongan Nomor 9/P1.02.7Kpt/3375/Kpu-Kot/I/2021 perihal Penetapan Pasangan Calon Walikota dan Wakil Walikota Terpilih dalam Pemilihan Walikota dan Wakil Walikota Pekalongan Tahun 2020 menetapkan H.A Afzan Arslan Djunaid, SE dan H Salahudin, STP menjadi Walikota dan Wakil Walikota Pekalongan Terpilih dengan Periode 2021 - 2026. 


\subsubsection{Implementasi Hukum Tata Negara pada Pemilihan Kepala Daerah Serentak di Saat Pandemi Covid -19}

Dalam tahapan pilkada tahun 2020 yang awalnya dilaksanakan pada bulan September 2020 ditunda disebabkan oleh pandemi Covid19, berdasarkan peraturan KPU maka pelaksanaan ditetapkan pada bulan Desember 2020 dan tertuang pada Peraturan Komisi Pemilihan Umum (PKPU) Nomor 5 Tahun 2020 pasal 8 b, pelaksanaan pemungutan suara serentak ini akan dilaksanakan pada tanggal 9 Desember 2020. Dalam penelitian ini penulis akan lebih banyak mengupas aspek hukum tata negara beserta implikasi dari pilkada tersebut, khususnya menyangkut hak-hak dasar masyarakat khususnya warga Kota Pekalongan yang berpotensi diabaikan saat pilkada digelar di masa pandemi Covid-19.

Pilkada di masa pandemi Covid-19 ini juga dikhawatirkan akan menurunnya minat para pemilih dari masyarakat, karena pada dasarnya tujuan pelaksanaan pilkada itu sendiri selain mencari pemimpin bagi masyarakat khususnya warga Kota Pekalongan dibutuhkan suara dan peran serta masyarakat dalam pemilihan itu sendiri. Kalau pilkada diselenggarakan di tengah pandemi Covid-19 kemungkinan masyarakat/pemilih akan enggan untuk mendatangi TPS karena rasa kekhawatiran terhadap virus Covid-19 itu sendiri, dan ditakutkan yang utama yaitu adanya kecurangan dalam perhitungan atau perolehan suara. Dikarenakan banyaknya kekhawatiran masyarakat yang mengakibatkan para pemilih kekurangan minat untuk datang ke tempat pemilihan, hal ini dapat menimbulkan kecurangan dalam perolehan suara di mana ditakutkan akan meningkatnya masyarakat yang memilih golput sehingga dikhawatirkan dapat disalahgunakan hak suara masyarakat yang tidak menggunakan hak suaranya, ditambah lagi Covid-19 ini menyerang berbagai kalangan tanpa terkecuali.

Salah satu tantangan utama dalam gelaran pilkada serentak di tengah pandemi yang terberat adalah respon pemilih dalam pilkada tersebut. Risiko dan bahayanya terpapar virus Covid-19 adalah menjadi pertimbangan pokok yang menjadi alasan pemilih untuk terlibat langsung dalam menyalurkan hak pilihnya, KPU Kota Pekalongan telah memberikan jaminan rasa aman bagi petugas KPPS serta warga dalam menyalurkan hak pilihnya karena semua TPS sudah sesuai dengan protokol kesehatan dengan disediakan masker, hand sanitizer, faceshield, sarung tangan dan pemakaian APD serta rapid test bagi petugas KPPS.

Perlunya sosialisasi bagi warga masyarakat di seluruh daerah termasuk Kota Pekalongan yang menjadi vital untuk diagendakan secara khusus, mengingat pilkada di tahun 2020 berada dalam situasi darurat akibat bencana wabah, artinya di sini bahwa ada opini publik yang saat ini berseteru, harus dijadikan dasar untuk menentukan langkah-langkah selanjutnya. Selain itu keputusan dan kebijakan dibuat harus menjembatani kepentingan orang banyak.

Dalam kegiatan kampanye KPU secara tegas telah menetapkan PKPU Nomor 13 Tahun 2020 pasal 58 menyatakan bahwa pelaksanaan kampaye dilaksanakan melalui media sosial atau media daring, apabila tidak dapat melaksanakn secara daring maka dibolehkan mengadakan pertemuan tatap muka dengan peserta paling banyak 50 orang dengan protokol kesehatan yang ketat. Pada Pasal 88C KPU dengan tegas melarang melaksanakan kegiatan yang mengumpulkan massa dengan jumlah besar dengan kampaye di media sosial mungkin bisa menjangkau para pemilih. Namun perlu diwaspadai sebagian besar kampanye beralih ke ruang virtual ancaman disinformasi dan berita hoaks.

Pelaksanaan dari konsep negara hukum seharusnya diutamakan sebagai prioritas dalam sebuah pilkada yang sedianya dilaksanakan di tengah-tengah pandemi Covid-19. Isu SARA dalam konteks pilkada yang demokratis tidak boleh muncul di permukaan ini karena akan menimbulkan disintegrasi Bangsa Indonesia karena dalam prinsip NKRI dan Bhinneka Tunggal Ika menjadi salah satu pilar penting dalam keberlangsungan kehidupan berbangsa dan bernegara termasuk dalam konteks pilkada langsung dan serentak dalam menghadapi wabah Covid-19. 
Jika pilkada itu gagal, justru berpotensi melahirkan suatu problem konstitusional yang berdampak luas dalam penyelenggaraan pemerintahan daerah. Problem konstitusional tersebut, disebabkan karena tidak sejalannya dengan kaidah prinsip negara hukum yang memenuhi aspek jaminan perlindungan kepastian hukum yang adil dengan pemenuhan hak konstitusional memilih dan dipilih sebagai amanah konstitusi untuk menghindari potensi ketidakpastian kekosongan jabatan yang berkepanjangan.

Sebagai negara hukum yang beradab dan berbudaya Pancasila, hukum ditempatkan sebagai panglima tertingi. Perlunya ada satu perubahan kepemimpinan daerah dengan kata lain pilkada serentak harus tetap dilaksanakan dengan walaupun situasi dan kondisi yang menyesuaikan keadaan pandemi Covid-19 yang terjadi saat ini.

\section{SIMPULAN DAN SARAN}

\subsection{Simpulan}

Pemilihan kepala daerah langsung pada masa pandemi Covid-19 dalam perspektif Hukum Tata Negara (HTN) merupakan dasar teori dari pelaksanaan penyelenggaraan negara yang mengatur hubungan antara lembaga negara baik secara horisontal ataupun vertikal dari pusat sampai daerah salah satunya adalah sistem politik demokratis yang teraplikasikan dalam sebuah pemilihan umum dan pemilihan kepala daerah. Hukum Tata Negara mengatur periodesasi pemilihan umum secara berkala dan periodik yang dilakukan setiap 5 (lima) tahun sekali. Pergantian pimpinan daerah sebagaimana dimaksud dilakukan secara serentak dan demokratis meskipun pada saat ini bangsa Indonesia sedang bertarung melawan wabah Covid-19 namun dengan protokol kesehatan yang sangat ketat serta aturan pelaksanaan pilkada yang terencana dan aman bagi warga masyarakat terutama warga Kota Pekalongan, maka diharapkan akan terpilihnya kepala daerah secara demokratis dan mampu menghasikan pemimpin daerahnya yang lebih baik dan maju .

\subsection{Saran}

1) Komisi Pemilihan Umum (KPU), Badan Pengawas Pemilu (Bawaslu) dan anggota
Dewan Kehormatan Penyelenggara Pemilu hendaknya menjaga kemandirian integritas, dan kredibilitasnya. Disarankan dan diharapkan agar dalam penyelenggaraan pemilu, khususnya Pemilihan Umum Walikota dan Wakil Walikota tahun 2024 mendatang dapat diselenggarakan lebih baik, demokratis, jujur dan adil.

2) Masyarakat khususnya Kota Pekalongan dalam pilkada mendatang diharapkan lebih partisipatif dan tertib aturan dalam mendukung salah satu calon walikota dan wakil walikota, supaya tercipta masyarakat Kota Pekalongan yang cinta damai, jauh dari potensi pemilu yang tidak jujur, manipulasi kekuasaan, politik uang, kampanye gelap, maupun ancaman berupa intimidasi kekerasan dan berbagai tindakan pelanggaran yang menjadikan proses demokrasi tidak berjalan baik dan tetap sesuai dengan protokol kesehatan .

\section{REFERENSI}

Alim, N (2020), Dampak Penundaan Pilkada Serentak 2020 di Tengah Pandemi Covid19 , Antara Megapolitan. https://megapolitan, anataranews.com/berit a/93100/dampak-penundaan-pilkadaserentak-2020-di-tengah-pandemi-covid$\underline{19}$

Asshiddiqie, J ( 2019) Konstitusi dan konsititusional Indonesia. Sinar Grafika Jakarta

G. Sorensen, (2013) Demokrasi dan Demokratisasi, Pustaka Pelajar, Yogyakarta,

Kristian, K (2017) Dinamika Pemekaran Daerah di Indonesia Menurut UndangUndang Nomor 23 Tahun 2014 tentang Pemerintahan Daerah. Jurnal Ilmu Hukum Universitas Palangka Raya 12(2).

Lontoh, A.L.,Lolong, W., \& Pangalila, T (2016). Hukum dan HAk Asasi Manusia. Ombak Yogyakarta 
Marzuki, M.(2017), Penelitian Hukum , Edisi Revisi. Prenada Media Jakarta

MD, M. M ( 2009), Konstitusi Hukum dalam Kontroversi isu,. Rajawali Pers Jakarta

Susanti , D.O., \& others. (2015) Penelitian Hukum, Sinar Grafika Jakarta

\section{Peraturan Perundang-Undangan}

Undang-Undang Dasar Negara Republik Indonesia Tahun 1945

Peraturan Pemerintah Pengganti UndangUndang Nomor 2 Tahun 2009

Undang-Undang Nomor 23 Tahun 2014 Tentang Pemerintahan Daerah

Peraturan Komisi Pemilihan Umum Nomor 5 Tahun 2020 